NOTE

\title{
Goussia molnarica n. sp. (Apicomplexa: Coccidia) infecting the gut of the freshwater catfish Clarias gariepinus in Egypt
}

\author{
Amina El-Mansy* \\ National Institute of Oceanography and Fisheries (NIOF), 101 Kaser El-Einii St., Cairo, Egypt
}

\begin{abstract}
A new coccidian (Apicomplexa: Coccidia), Goussia molnarica n. sp., is described from the gut of the African catfish Clarias gariepinus Bürchell, 1822. Elliptical sporulated oocysts measuring 14-16 $\times 9-10 \mu \mathrm{m}$ were found in the feces and in the mucus covering the epithelium in $40.6 \%$ of examined catfish specimens. In histological sections, G. molnarica macrogamonts were found, infecting the first part of the intestinal epithelium. Infection prevalence was highest in April and lowest in November. The pathology of infection resembled disperse coccidioses of cyprinid fishes caused by various other species of the genus Goussia Labbé, 1896.
\end{abstract}

KEY WORDS: Coccidian species · Goussia molnarica • Gut · Freshwater catfish Clarias gariepinus • Egypt Resale or republication not permitted without written consent of the publisher

\section{INTRODUCTION}

Little is known about the coccidian infection of fish in Africa; however, data have been presented by Landsberg \& Paperna (1987), Diouf \& Toguebaye (1996), Molnár et al. (2004) and El-Mansy (2008). Currently no coccidia have been described from the African catfish, though Paperna (1996), without giving detailed information, mentioned the occurrence of a Goussia-like species from the gut of Clarias gariepinus.

In the present study, a new Goussia species, G. molnarica n. sp., from the African catfish Clarias gariepinus is described, and data concerning its occurrence, seasonality and location in the host are presented.

\section{MATERIALS AND METHODS}

Sixty-nine catfish Clarias gariepinus Bürchell, 1822 from the River Nile were obtained in 2006 from several sources including fish markets, particularly those of Al-Qanater city. The fish were kept alive in aquaria for 1 to $3 \mathrm{~d}$ before parasitological examination. Fresh preparations from the intestinal tract were examined for the presence of oocysts. After opening the intestine, mucus and epithelial scrapings, as well as some pieces of feces, were placed on slides under a cover slip, then examined for the presence of oocysts. Infected portions of the gut were fixed for histological examination in $10 \%$ buffered formalin. Tissues were embedded in paraffin wax, serially sectioned and stained with haematoxylin and eosin. Oocysts were measured by a calibrated ocular micrometer. Schematic drawings of sporulated oocysts were prepared. Photos were taken using a digital camera attached to the microscope. The intensity of infection was graded by examining the number of oocysts of 10 intestinal scrapings. The infection was regarded as low when by $200 \times$ microscopic enlargement $<50$ oocysts were found; medium, 50 to 200 oocysts; and high, >200 oocysts. 


\section{RESULTS}

Clarias gariepinus specimens $(\mathrm{n}=69)$ measured 18 to $40 \mathrm{~cm}$ and weighed 76.5 to $900 \mathrm{~g}$ (Table 1). Twentyeight infected specimens of the examined African catfish $(40.6 \%)$ harbored oocysts of an unknown species; large elliptical oocysts were found in the gut throughout the year. Oocysts were found mainly in the mucus covering the epithelium of the foregut, but were also found in the feces and scrapings of the gut epithelium. The prevalence of infection was highest during the spring (April) $(66.7 \%)$. In autumn (November), a relatively moderate prevalence $(30.8 \%)$ was recorded (Table 1). No relation was found between host size and the prevalence and intensity of infection.

\section{Description of the elliptical-shaped Goussia molnarica n. sp.}

Oocysts were mostly observed by the end of the winter (Fig. 1a,b). This type of Goussia developed continuously and was found during the whole year; there were seasonal differences only in the prevalence and intensity of infection. Sporulated oocysts were elliptical or somewhat irregular. They measured approximately 13.6 to $16.3 \mu \mathrm{m}$ (mean $14.4 \pm 1.0 \mathrm{SD})$ in length and 9.7 to $13.9 \mu \mathrm{m}(10.9 \pm$ 1.7) in width (Table 2). Elliptical oocysts had similarly compact sporocysts so they do not seem to be species developing over a $1 \mathrm{yr}$ cycle. Walls of the oocyst were smooth, colourless and thin. Micropyle, oocyst residuum and polar granules were absent. Oocysts contained 4 elongated ellipsoidal sporocysts arranged, in most cases, in different directions. Generally, 3 sporocysts were seen in 1 plane in the oocyst, and the 4th sporocyst was located behind them (Fig. 2a,b). Sporocysts measured 7.5 to $10.6 \mu \mathrm{m}(7.8 \pm 1.3)$ long and 3.9 to $7.0 \mu \mathrm{m}(5.6 \pm 0.9)$ wide. Two vermiform sporozoites with reflexed ends were located in sporocysts head to tail. Sporozoites measured 5.5 to $9.1 \mu \mathrm{m}(6.8 \pm 1.1) \times 0.7$ to $2.1 \mu \mathrm{m}(1.7 \pm 0.5)$. Sporocyst walls were thin, and stieda-like formations were not seen. The sporocyst residuum in young spores was a large globule, measuring 1.2 to $2.5 \mu \mathrm{m}(2.0 \pm 0.5)$, in elder spores it was composed of small scattered granules, 0.5 to $1.1 \mu \mathrm{m}(0.7 \pm 0.3) \times 1.6$ to $2.3 \mu \mathrm{m}(1.9 \pm 0.3)$, length $\times$ width and 0.3 to $0.7 \mu \mathrm{m}(0.5 \pm 0.2)$ in diameter. The majority of oocysts were found in a sporulated state.
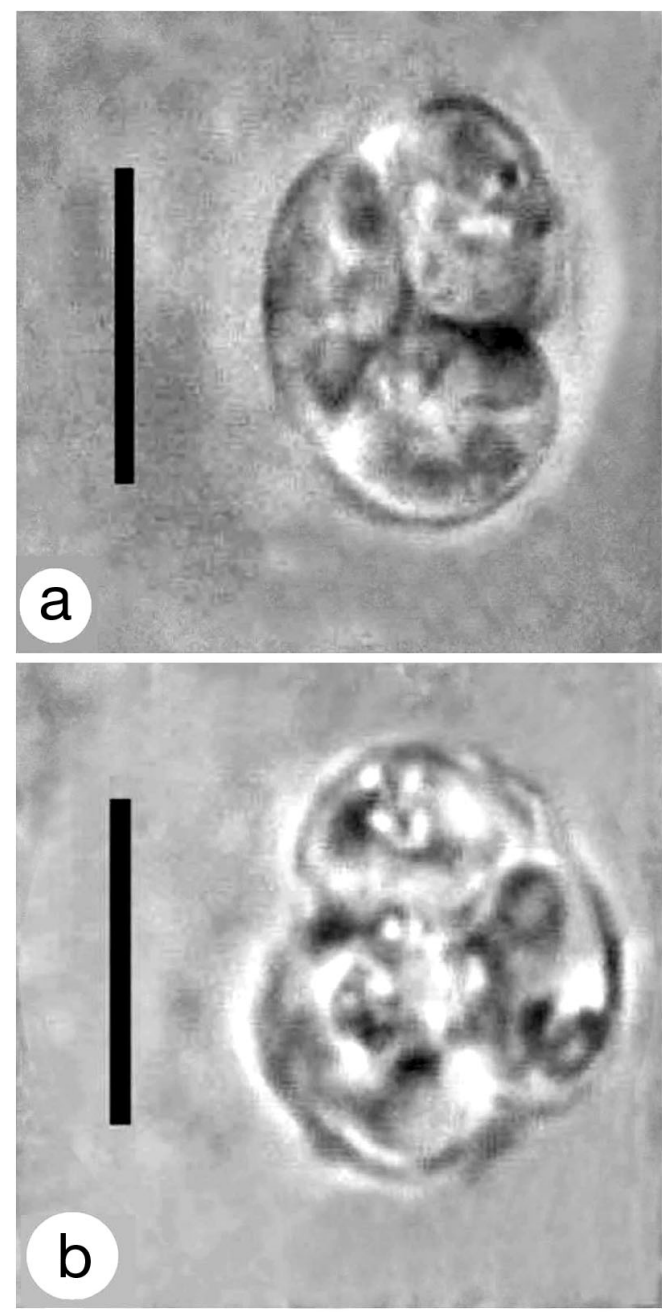

Fig. 1. Goussia molnarica n. sp. Sporulated oocyst. (a) Three ellipsoidal sporocysts can be seen in the upper plane of the oocyst. Fresh preparation from a mucosal scraping of the intestine of Clarias gariepinus. (b) Sporocysts in a different position. Among sporozoites globule sporocyst residuum can be seen. Scale bar $=10 \mu \mathrm{m}$

Table 1. Length, weight and intensity of infection of Clarias gariepinus with stages of Goussia molnarica at different seasons. $\mathrm{n}$ : number of measured and weighed fish, no. infected: number of infected fish, no. examined: number of examined fish, M: moderate, H: heavy

\begin{tabular}{|c|c|c|c|c|c|c|c|}
\hline Season & $\begin{array}{l}\text { Length }(\mathrm{cm}) \\
\text { Size range }(\text { mean } \pm \mathrm{SD})\end{array}$ & $\begin{array}{c}\text { Weight }(g) \\
\text { Size range }(\text { mean } \pm \mathrm{SD})\end{array}$ & $\mathrm{n}$ & $\begin{array}{c}\text { Prevalence } \\
(\%)\end{array}$ & $\begin{array}{c}\text { No. } \\
\text { infected }\end{array}$ & $\begin{array}{l}\text { No. } \\
\text { examined }\end{array}$ & $\begin{array}{l}\text { Intensity } \\
\text { of infection }\end{array}$ \\
\hline Summer & $19-35(28.3 \pm 6.8)$ & $80-324(188.8 \pm 87.1)$ & 3 & 33.3 & 7 & 21 & M \\
\hline Autumn & $18-35(27.0 \pm 7.0)$ & $80-325(189.2 \pm 87.5)$ & 3 & 30.8 & 3 & 10 & $\mathrm{M}$ \\
\hline Winter & $21-40(33.8 \pm 3.0)$ & $76.5-900(368.3 \pm 244.1)$ & 11 & 41.4 & 12 & 29 & $\mathrm{M}$ \\
\hline Spring & $30-39(34.3 \pm 3.5)$ & $200-225(218.5 \pm 10.7)$ & 4 & 66.7 & 6 & 9 & $\mathrm{H}$ \\
\hline
\end{tabular}


Table 2. Goussia spp. Comparison of 12 freshly isolated G. molnarica n. sp. of present study and some previously described species (measurements in $\mu \mathrm{m}$ ) found in different fish hosts. Data are ranges and/or mean $\pm \mathrm{SD}$

\begin{tabular}{|c|c|c|c|c|c|c|}
\hline Goussia species & $\begin{array}{l}\text { Oocyst } \\
\text { dimensions, } \\
\text { form }\end{array}$ & $\begin{array}{l}\text { Sporocyst } \\
\text { dimensions, } \\
\text { form }\end{array}$ & $\begin{array}{l}\text { Sporozoite } \\
\text { dimensions }\end{array}$ & $\begin{array}{l}\text { Sporocyst } \\
\text { residuum }\end{array}$ & Host & Source \\
\hline G. carpelli & $\begin{array}{l}7.8-11.6 \\
\text { spherical }\end{array}$ & $\begin{array}{l}6.2-8.1 \times 3.8-6.0 \\
\text { ellipsoidal }\end{array}$ & $8.5 \times 1.8$ & 2.4 & Cyprinus carpio & Lom \& Dyková (1992) \\
\hline G. kessleri & $\begin{array}{l}8.1(7.0-8.5) \\
\text { spherical }\end{array}$ & $\begin{array}{l}5.8(5.0-6.0) \times \\
3.9(3.8-4.0)\end{array}$ & $7.0 \times 1.5$ & - & Gobius kessleri & Molnár (2000) \\
\hline G. wakabayashii & $\begin{array}{l}8.5(8.0-9.0) \\
\text { spherical }\end{array}$ & $\begin{array}{l}7.0(6.5-7.5) \times \\
4.1(3.8-4.3)\end{array}$ & $\begin{array}{l}7.5(7.0-9.0) \times \\
1.3(1.0-1.5)\end{array}$ & $1.0-1.5$ & $\begin{array}{c}\text { Tridentlger } \\
\text { kuroiwae }\end{array}$ & Molnár \& Ogawa (2000) \\
\hline G. pogonognathi & $\begin{array}{l}10.0-13.0 \\
(11.1 \pm 1.16)\end{array}$ & $\begin{array}{l}8.0-11.0 \times \\
4.0-5.0 \\
(9.0 \times 4.5)\end{array}$ & $\begin{array}{l}8.0-9.0 \times \\
1.5-2.0 \\
(8.4 \times 1.8)\end{array}$ & $\begin{array}{l}2.0 \times 2.0 \text { or } \\
2.0 \times 1.0\end{array}$ & $\begin{array}{l}\text { Hemirhamphodon } \\
\text { pogonognathus }\end{array}$ & Molnár et al. (2003) \\
\hline G. anopli & $\begin{array}{l}8.0-9.0 \\
\text { spherical }\end{array}$ & $\begin{array}{l}5.0-5.5 \times \\
3.0-4.5\end{array}$ & $\begin{array}{l}7.0-8.0 \times \\
1.5-2.0\end{array}$ & $\begin{array}{l}1.5 \times 1.5 \text { or } \\
2.0 \times 1.5\end{array}$ & Barbus anoplus & Molnár et al. (2004) \\
\hline G. molnarica & $\begin{array}{l}13.6-16.3 \\
(14.4 \pm 1.0) \times \\
9.7-13.9 \\
(10.9 \pm 1.7)\end{array}$ & $\begin{array}{l}7.5-10.6 \\
(7.8 \pm 1.3) \times \\
3.9-7.0 \\
(5.6 \pm 0.9)\end{array}$ & $\begin{array}{l}5.5-9.1 \\
(6.8 \pm 1.1) \times \\
0.7-2.1 \\
(1.7 \pm 0.5)\end{array}$ & $\begin{array}{l}1.2-2.5 \\
(2.0 \pm 0.47) \times \\
1.6-2.3 \\
(1.9 \pm 0.3)^{\mathrm{a}} \\
0.5-1.1 \\
(0.7 \pm 0.25) \times \\
0.3-0.7 \\
(0.5 \pm 0.2)^{\mathrm{b}}\end{array}$ & $\begin{array}{l}\text { Clarias } \\
\text { gariepinus }\end{array}$ & Present study \\
\hline \multicolumn{6}{|c|}{${ }^{\mathrm{a}}$ Large, round, globular } & \\
\hline
\end{tabular}

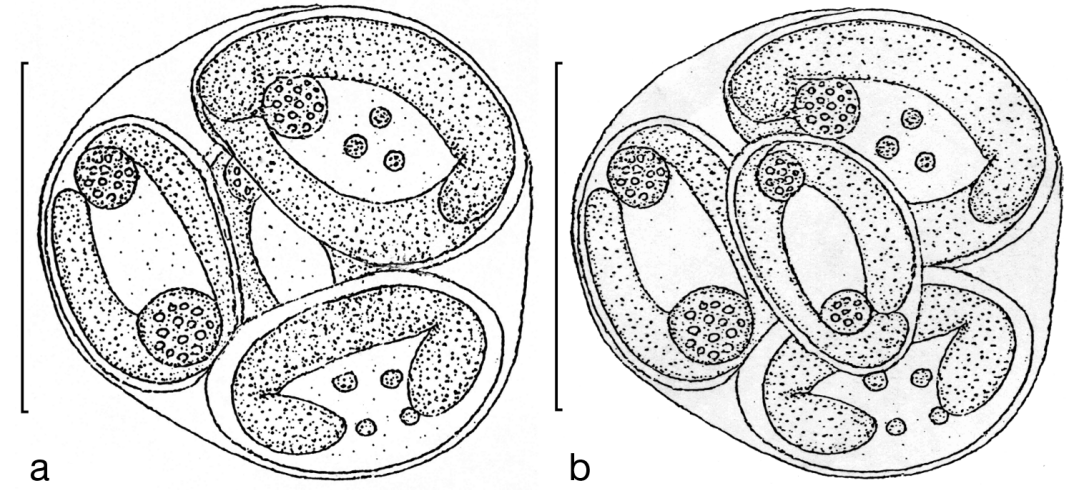

Fig. 2. Goussia molnarica n. sp. Schematic illustration of sporulated oocyst. (a) 3 sporocysts are seen in 1 plane in the oocyst with the 4th sporocyst behind them. (b) Oocyst contains 4 elongated ellipsoidal sporocysts arranged in different directions. Scale bar $=10 \mu \mathrm{m}$

Type host: African catfish Clarias gariepinus Bürchell, 1822.

Type locality: River Nile at Al-Qanater city $\left(30.17^{\circ} \mathrm{N}, 31.14^{\circ} \mathrm{E}\right)$.

Site of infection: Mucus and epithelium of the gut.

Prevalence of infection: 28/69 infected specimens, $40.6 \%$.

Intensity of infection: Sometimes heavy.

Phototypes: In the collection of the author.

Etymology: The specific epithet derives from the well-known Hungarian fish parasitologist Kálmán Molnár.
Histology: A gamogonic stage of Goussia molnarica was found in the epithelium of the intestine. Young stage macrogamonts developing in a parasitophorous vacuole were located inside epithelial cells. Macrogamonts (Fig. 3) measuring $8.5 \times 5.5 \mu \mathrm{m}$ were dispersed in the intestinal epithelium of the host, and caused only local damages.

\section{DISCUSSION}

Freshwater fishes, especially cyprinids, are frequently infected by different species of the genus Goussia. Little is known, however, about coccidian infections of silurid fishes. It seems that the African catfish Clarias gariepinus is commonly infected by Goussia molnarica n. sp., which may be specific to the catfish host. Other Goussia spp. known from Africa infect different hosts. Paperna (1996) listed Goussia-like species from the gut of C. gariepinus from freshwater fishes in Africa.

The prevalence and intensity of infection with fish coccidia is mostly influenced by water temperature (Molnár 2006). In temperate climatic zones, intensive infections have been found mostly in the spring and the summer (Odense \& Logan 1976, Baska 1997, Mol- 


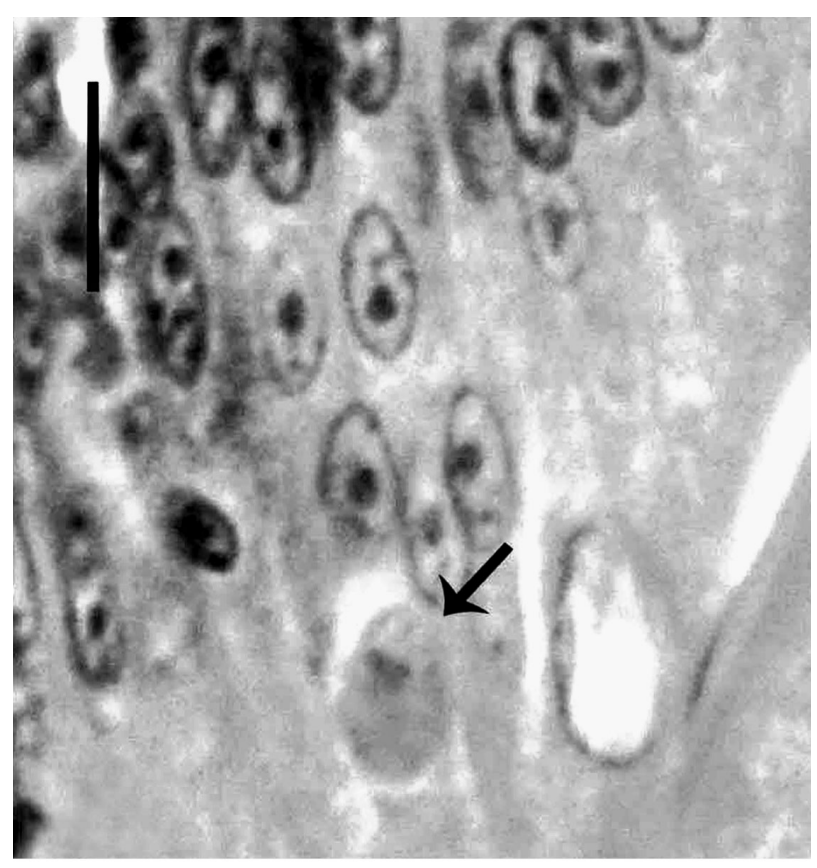

Fig. 3. Goussia molnarica n. sp. Macrogamont inside a parasitophorous vacuole (arrow) in the cytoplasm of an epithelial cell. Histological section of the intestinal epithelium. H \& E staining. Scale bar $=10 \mu \mathrm{m}$

nár \& Ogawa 2000, Molnár et al. 2004). Though the water temperature in the Nile is higher than in temperate zone rivers, it seems there is a similar seasonal effect on the development of fish parasites. In Egypt, the highest prevalence and intensity of infection were found from April to June, and the lowest prevalence was observed during November.

The location of oocysts in the gut of infected fish seems to follow the same pattern which characterizes Goussia sinenis Chen, 1956, G. iroquoina Molnár \& Fernando, 1974 and G. carpelli as reported by Molnár et al. (2004). Oocysts seem to develop inside the epithelial cells but after sporulation they may be suppressed to subepithelial sites. In histological sections, G. molnarica was found to occur in similar sites in the gut as G. vanasi (Kim \& Paperna 1992). The species found during the present study appears to be typical representatives of the disperse coccidian group which develop in the intestinal epithelium of host fish similar to the above-listed species and the African species $G$. anopli (Molnár et al. 2004). Although pathogenic effects could not be detected in the present study, it cannot be excluded that this species can be pathogenic in intensive cultures.

The species found in this investigation (Goussia molnarica) has relatively large oocysts with ellipsoid sporocysts, and resembles - in most features-G. anopli, G. carpelli, G. kessleri, G. wakabayashii and G. pogonognathi (see Table 2). The majority of these species are of similar size and shape, but, besides infecting different hosts, they differ from G. molnarica in several ways. Small-sized Goussia seem to have host specificity (Lukeš et al. 1991); previous research has indicated that $G$. carpelli is specific to the common carp and does not infect the closely related goldfish (Molnár 2006).

Goussia molnarica closely resembles Eimeria ojibwana (Molnár \& Fernando 1974) and E. cheilodactyli (Molnár \& Rohde 1988) in that it has scattered coarse granules and 2 reflexed vermiform sporozoites arranged head to tail in sporocysts. However, the shape and size of sporocyst residua cannot be considered an important feature for identification, as the size and shape of the residuum depends on the age of the oocyst.

Acknowledgements. The author thanks A. Badawy for his kind encouragement. Thanks also to K. Molnár for his advice during his official visit to NIOF, Egypt and for reviewing the manuscript.

\section{LITERATURE CITED}

Baska F (1997) Epicellular and nodular coccidiosis in the intestine of barbell Barbus barbus. Dis Aquat Org 29: $49-56$

Diouf JN, Toguebaye BS (1996) Eimeria spari n. sp. (Apicomplexa, Eimeriidae) parasite of Sparus caeruleostictus (Valenciennes, 1830), (Pisces, Sparidae) from the coast of Senegal. Parasite 3:351-355

El-Mansy A (2008) New exogenous stages of oocysts, sporocysts and sporozoites of Goussia cichlidarum Landsberg and Paperna 1985 (Sporozoa: Coccidia) and impact of endogenous stages on the swim bladder of tilapias in Egypt. Parasitol Res 102:233-241

Kim SH, Paperna I (1992) Fine structure of epicytoplasmic stages of Eimeria vanasi from the gut of cichlid fish. Dis Aquat Org 12:191-197

Landsberg JH, Paperna I (1987) Intestinal infections by Eimeria (S. L.) vanasi n. sp. (Eimeriidae Apicomplexa Protozoa) in cichlid fish. Ann Parasitol Hum Comp 62:283-293

Lom J, Dyková I (1992) Protozoan parasites of fishes. Developments in aquaculture and fisheries science, Vol 26. Elsevier, Amsterdam, p 159-235

Lukeš J, Steinhagen D, Körting W (1991) Goussia carpelli (Apicomplexa, Eimeriorina) from cyprinid fish: field observations and infection experiments. Angew Parasitol 32: 149-153

Molnár K (2000) Two new coccidia, a Goussia and Eimeria spp. from the gut of Kessler's goby (Gobius kessleri Günther) in the River Danube. Acta Protozool 39:323-329

Molnár K (2006) Phylum Apicomplexa. In: Woo PTK (ed) Fish diseases and disorders, Vol 1, 2nd edn: Protozoan and metazoan infections. CABI Publishing, Wallingford, p 183-204

Molnár K, Fernando CH (1974) Some new Eimeria (Protozoa, Coccidia) from freshwater fishes in Ontario, Canada. Can J Zool 52:413-419

Molnár K, Ogawa K (2000) A survey on coccidian infection of 
Lake Biwa fishes in Japan, with the description of four new species of Goussia Labbé, 1896 (Apicomplexa). Syst Parasitol 47:215-222

Molnár K, Rohde K (1988) Seven new coccidian species from marine fishes in Australia. Syst Parasitol 11:19-29

Molnár K, Shaharom-Harrison F, Székely C (2003) A survey of coccidian infection of freshwater fishes of Peninsular Malaysia, with descriptions of three species of Goussia Labbé, 1896 (Apicomplexa: Eimeriidae). Syst Parasitol 55:11-18

Editorial responsibility: Dieter Steinhagen,

Hannover, Germany
Molnár K, Oldewage AO, Székely C (2004) A survey of coccidian infection of freshwater fishes in South Africa, with the description of Goussia anopli n. sp. (Apicomplexa: Eimeriidae). Syst Parasitol 59:75-80

> Odense PH, Logan VH (1976) Prevalence and morphology of Eimeria gadi (Fiebiger, 1913) in the haddock. J Protozool 23:564-571

Paperna I (1996) Parasites, infections and diseases of fishes in Africa: an update. CIFA Techn Pap no. 31, FAO, Rome

Submitted: March 20, 2008; Accepted: August 12, 2008

Proofs received from author(s): October 30, 2008 